\title{
Reversibility of deleterious effects of the pisciculture byproduct nitrite on cultured Nile tilapia (Oreochromis niloticus)
}

\author{
Maristela Azevedo ${ }^{1}$, Marta M. Souza ${ }^{2}$ and Carolina A. Freire ${ }^{1, a}$ \\ 1 Departamento de Fisiologia, Setor de Ciências Biológicas, Universidade Federal do Paraná, Curitiba, Paraná, Brazil \\ 2 Departamento de Ciências Fisiológicas, Universidade Estadual de Londrina, Londrina, Paraná, Brazil
}

Received 21 May 2003; Accepted 17 September 2003

\begin{abstract}
The effects of nitrite $\left(\mathrm{NO}_{2}^{-}\right)$on the Nile tilapia (Oreochromis niloticus) were investigated, due to their relevance to worldwide aquaculture. Hematological parameters - functional haemoglobin (oxy+deoxy-Hb, \%), methaemoglobin $(\mathrm{MetHb} \%)$, and hematocrit $(\mathrm{Hct})$ - and - plasma osmolality, plasma chloride $\left(\left[\mathrm{Cl}^{-}\right]\right)$and magnesium $\left(\left[\mathrm{Mg}^{2+}\right]\right)$ concentrations - were analysed. Two experiments were conducted, each with its own non-contaminated control, 8 tilapias for each group. In experiment 1 (48 hours), and the first 48 hours of experiment 2, fish were contaminated with $0.4 \mathrm{mM} \mathrm{NO}_{2}^{-}$(added as $\mathrm{NaNO}_{2}$ ). In experiment 2, ambient $\mathrm{NaNO}_{2}^{-}$was removed for the second 48 hours. $\mathrm{NaNO}_{2}^{-}$ exposure increased plasma $\left[\mathrm{NO}_{2}^{-}\right]$to $0.4 \mathrm{mM}$, which increased MetHb from $10.8 \pm 2.5 \%$ to $46.8 \pm 8.0 \%$, and consequently decreased functional $\mathrm{Hb}$ from $89.2 \pm 2.5 \%$ to $53.2 \pm 8.0 \%$. $\mathrm{NaNO}_{2}$ removal led to recovery of both parameters. Both Hct and plasma $\mathrm{Mg}^{2+}$ were lowest in fish recovering from nitrite exposure. Thus, these parameters did not show recovery. Plasma osmolality and $\left[\mathrm{Cl}^{-}\right]$were not affected by $\mathrm{NaNO}_{2}^{-}$, probably due to the moderate rise in plasma $\left[\mathrm{NO}_{2}^{-}\right]$. O. niloticus was thus sensitive to 48 hours of exposure to $0.4 \mathrm{mM} \mathrm{NaNO}_{2}$, and partially recovered from its effects after 48 hours in sodium nitrite-free water. Cultivators of Nile tilapia should thus consider the toxicity of nitrite, especially in aquaculture systems using recirculating water.
\end{abstract}

Key words: Aquaculture / Methaemoglobin / Nile tilapia / Nitrite / Oreochromis / Osmoregulation

Résumé - Réversibilité des effets nocifs des nitrites, rejets de pisciculture, sur le tilapia (Oreochromis niloticus). Les effets des nitrites $\left(\mathrm{NO}_{2}^{-}\right)$sur le tilapia (Oreochromis niloticus) sont étudiés, en raison de leur importance en aquaculture. Différents paramètres sanguins ont été analysés sur le sang entier, hémoglobine fonctionnelle (oxy+désoxy-Hb, \%), méthémoglobine (MetHb, \%), hématocrite (Hct), et sur le plasma, osmolalité, concentrations en chlore $\left(\left[\mathrm{Cl}^{-}\right]\right)$et en magnésium $\left(\left[\mathrm{Mg}^{2+}\right]\right)$. Deux expériences sont conduites, chacune effectuée sur un groupe de 8 tilapias, avec chacune un groupe témoin (non contaminé). Dans la $1^{\text {ère }}$ expérience, les poissons ont été exposés pendant $48 \mathrm{~h}$ à $0,4 \mathrm{mM} \mathrm{NO}_{2}^{-}$(apports sous forme de $\mathrm{NaNO}_{2}$ ). Dans la seconde expérience, l'apport de $\mathrm{NO}_{2}$ exogène est arrêté après $48 \mathrm{~h}$ (d'exposition) et les poissons, durant les $48 \mathrm{~h}$ suivantes, sont placés en eau sans apport exogène de nitrites. L'exposition à $\mathrm{NO}_{2}^{-}$induit une augmentation de la concentration en $\left[\mathrm{NO}_{2}^{-}\right]$plasmatique, qui atteint $0,4 \mathrm{mM}$, en MetHb, de 10,8 $\pm 2,5 \%$ à 46,8 $\pm 8,0 \%$, et donc une diminution de l'hémoglobine fontionnelle, Hb de 89,2 $\pm 2,5 \%$ à 53,2 $\pm 8,0 \%$. Après l'arrêt de l'apport en $\mathrm{NO}_{2}^{-}$, Hct et $\left[\mathrm{Mg}^{2+}\right]$ plasmatique restent plus faibles qu'initialement, indiquant une récupération partielle des poissons après $48 \mathrm{~h}$. L'osmolalité et $\left[\mathrm{Cl}^{-}\right]$du plasma ne sont pas affectés par l'exposition à $0,4 \mathrm{mM}$ de $\mathrm{NO}_{2}^{-}$, probablement en raison de l'augmentation modérée de $\left[\mathrm{NO}_{2}^{-}\right]$plasmatique. O. niloticus est ainsi sensible à $48 \mathrm{~h}$ d'exposition à $0,4 \mathrm{mM}\left(\mathrm{NaNO}_{2}\right)$ et ne récupère que partiellement après $48 \mathrm{~h}$ en eau sans apport exogène. Les éleveurs de ce tilapia doivent tenir compte de la toxicité des nitrites, spécialement lorsque l'élevage est pratiqué en circuit fermé.

\section{Introduction}

The high fish density in intensive culture units supplied with recirculating water frequently results in raised water nitrite $\left(\mathrm{NO}_{2}^{-}\right)$levels. Nitrite is generated from nitrogenous

\footnotetext{
a Corresponding author: cafreire@ufpr.br
}

wastes, due to the incomplete oxidation of ammonia to nitrate (Atwood et al. 2001; Jensen 2003), and is highly toxic to many freshwater vertebrates and invertebrates, with fish being especially sensitive (Bianchini et al. 1995; Doblander and Lackner 1996; Jensen 2003). $\mathrm{NO}_{2}^{-}$is a strong inducer of the conversion of normal haemoglobin $(\mathrm{Hb})$ to methaemoglobin (MetHb), through the oxidation of $\mathrm{Hb}$ iron. MetHb can cause 
fish death by hypoxia, as it reduces the amount of functional $\mathrm{Hb}$ in the erythrocytes, and reduces the hematocrit as well (Jensen 2003). $\mathrm{NO}_{2}^{-}$in water competes with chloride for the chloride binding site of the branchial $\mathrm{Cl}^{-} / \mathrm{HCO}_{3}^{-}$exchanger, thus entering into freshwater fish, and may concentrate in the fish body to values far above the levels found in water, especially in water with chloride concentration in the micromolar range (Jensen 2003). Nitrite thus affects freshwater fish osmoregulation. Once inside the fish body, nitrite can penetrate tissues, leading to hypoxia of vital organs such as the liver (Jensen et al. 1987). Experiments with nitrite contamination using the carp Cyprinus carpio report that the effects of exposure to nitrite for 48 hours can be reversed by removing the animals from the presence of the contaminant, although the elimination of the contaminant occurs at a lower rate than its uptake (Jensen et al. 1987). After 2 days of exposure, 5 days of recovery lead to a reduction in the induced methaemoglobinemia (Knudsen and Jensen 1997). The Nile tilapia, Oreochromis niloticus, is a native of the African continent, but occurs worldwide and is extensively used for aquaculture, due mainly to its high rates of reproduction and growth, as well as its climatic and environmental plasticity. Despite their relevance in aquaculture, their tolerance to nitrite has only been studied relative to nitrite toxicity and fish size, larger (adult, 90 g weight) specimens have shown to be more sensitive than young specimens ( $\sim$ g weight) (Atwood et al. 2001). The objective of the present study is to evaluate nitrite toxicity (and its reversibility) in Nile tilapia, through its effect on haemoglobin, hematocrit, and plasma osmoregulation.

\section{Materials and methods}

\subsection{Fish acclimation}

O. niloticus $(13.8 \pm 0.4 \mathrm{~cm}, n=31$, total length, mean \pm SEM) were obtained from pisciculture tanks of the Experimental Farm of the Federal University of Paraná, Pinhais, Paraná. In the laboratory, fish were acclimated in 70liter stock tanks filled with dechlorinated tap water (salinity $<0.5 \%$ ) , temperature of $24-26^{\circ} \mathrm{C}$, for a minimum of 5 days.

\subsection{Experiments}

For the experiments, each tilapia was maintained individually in 20-liter aquaria laterally covered with green paper, in order to avoid stress (Volpato and Fernandes 1994; Volpato and Barreto 2001). One control group (without nitrite) was established for each of the 2 experiments. Experiment 1 consisted of 48 hours of nitrite contamination; experiment 2 consisted of 48 hours of nitrite contamination followed by 48 hours without nitrite, to test for a reversible effect. In experiment 2 , fish were transferred from their $\mathrm{NO}_{2}^{-}$contaminated aquarium to another aquarium without added $\mathrm{NO}_{2}^{-}$. Controls were manipulated likewise. All groups consisted of 7-8 tilapias. Control and contaminated fish were fed regular tropical fish food (Alcon Basic ${ }^{\circledR}$ ) daily, except for the 48 hours of experiment 1 , and the first 48 hours of experiment 2.

\subsection{Nitrite contamination}

Aquarium water was contaminated with the addition of $\mathrm{NaNO}_{2}$, resulting in an initial concentration of $0.4 \mathrm{mM} \mathrm{NO}-$. Water nitrite concentrations were measured employing the Griess reaction of nitrite with sulfanilamide, which when combined with N-1-naftil-ethylenoamine-dihydrochloride, produces a pinkish product detectable at $543 \mathrm{~nm}$ (Bendschneider and Robinson 1952). Water samples collected after 24 hours in the aquarium with the tilapia had $0.19 \pm 0.01 \mathrm{mM}(n=8)$ measured $\mathrm{NO}_{2}^{-}$, probably the result of nitrite uptake by the tilapia, and nitrite oxidation or reduction. Water from either control aquaria, or aquaria from experiment 2 in the last 48 hours had zero measured $\mathrm{NO}_{2}^{-}(n=9)$. All aquaria were maintained under constant aeration, had their water temperature and $\mathrm{pH}$ measured daily, as well as fifty percent of their water replaced, every day, to avoid ammonia accumulation.

\subsection{Aquarium water temperature and $\mathrm{pH}$}

Water temperature and water $\mathrm{pH}$ in experiment 1 were respectively $24.6 \pm 0.3{ }^{\circ} \mathrm{C}$ and $7.39 \pm 0.02, n=32$ determinations, mean \pm SEM, from 8 control and 8 contaminated aquaria measured daily, for 48 hours. Water temperature and water $\mathrm{pH}$ in experiment 2 were respectively $26.7 \pm 0.2{ }^{\circ} \mathrm{C}$ and $7.45 \pm 0.01$, $n=60$ determinations, mean \pm SEM, from 8 control and 7 contaminated aquaria measured daily, for 96 hours. Both temperature and $\mathrm{pH}$ were different between experiments 1 and 2 $(p<0.05)$.

\subsection{Blood sample collecting and processing}

After the 48 hours of experiment 1 or the 96 hours of experiment 2 , fish were anesthesized with benzocaine $\left(80 \mathrm{mg} \mathrm{l}^{-1}\right)$ added to the water of a 11-container. After the fish was laying on its side ( $\sim 2 \mathrm{~min})$, a blood sample was withdrawn from the caudal vein using heparinized syringes. Standard and total fish lengths were also obtained after the blood collection. The blood sample was centrifuged (2100 xg for $5 \mathrm{~min}$ ), plasma was obtained and frozen at $-20{ }^{\circ} \mathrm{C}$ until assayed for osmolality and ion concentrations. A heparinized glass capillary was filled with freshly collected blood and the sample hematocrit was recorded after $5 \mathrm{~min}$ of centrifugation at $12000 \mathrm{rpm}$, using a hematocrit centrifuge (CMH 28, Presvac, Argentina). A fresh blood sample was also used for functional $\mathrm{Hb}$ (defined as oxy + deoxyhaemoglobin) and methaemoglobin determinations (Benesh et al. 1973). Plasma osmolality was read using the VAPRO 5520 micro-osmometer (Wescor, USA), and chloride and magnesium determinations were performed colorimetrically, using commercially available kits (Labtest, Brazil).

\subsection{Statistical analysis}

The effect of treatment on each of the 6 variables (mean \pm SEM) was assessed through one-way ANOVAs followed by Tukey's post hoc test to localize significant differences between control and contaminated groups within experiment 1 
or 2, or between both controls or both contaminated groups. Temperature, $\mathrm{pH}$ and plasma nitrite values were compared using Student's $t$ test. The level of significance was always $p<0.05$, and the software used was Sigma Stat ${ }^{\circledR}$ v. 2.03 .

\section{Results}

One-way ANOVAs indicate an effect of treatment on all 3 hematological parameters (Fig. 1), and all 3 osmoregulatory parameters (Fig. 2). The percentage of functional haemoglobin (oxy+deoxy $\mathrm{Hb}$ ) was reduced upon 48 hours of nitrite exposure, from $89.2 \pm 2.5 \%$ to $53.2 \pm 8.0 \%$ (Fig. 1a), due to a rise in MetHb from $10.8 \pm 2.5 \%$ to $46.8 \pm 8.0 \%$ (Fig. 1b). An additional 48 hours without nitrite (reversal experiment) led to a recovery of both parameters: $84.2 \pm 6.5 \%$ for functional $\mathrm{Hb}$ and $17.7 \pm$ $5.4 \%$ for MetHb (Figs. 1a,b). The third hematological parameter analysed, Hct, was significantly reduced only after 48 hours with $\mathrm{NO}_{2}^{-}$followed by 48 hours without $\mathrm{NO}_{2}^{-}(9.1 \pm 2.0 \%)$, when compared to their controls $(27.6 \pm 6.3 \%$, Fig. 1c). The same result was observed for plasma $\left[\mathrm{Mg}^{2+}\right]$ : $0.64 \pm 0.07 \mathrm{mM}$ against $1.39 \pm 0.09 \mathrm{mM}$ for their controls (Fig. 2c). There was no effect of nitrite exposure on plasma osmolality and $\left[\mathrm{Cl}^{-}\right]$. The fish used for the reversal experiment (experiment 2) displayed lower values of plasma osmolality and chloride than the fish used in experiment 1 (Figs. 2a,b). Tilapias exposed to nitrite in experiment 2 displayed lower osmolality levels $\left(228.3 \pm 17.9 \mathrm{mOsm} \mathrm{kg}^{-1} \mathrm{H}_{2} \mathrm{O}\right)$ than tilapias exposed to nitrite in experiment $1\left(322.8 \pm 28.3 \mathrm{mOsm} \mathrm{kg}^{-1} \mathrm{H}_{2} \mathrm{O}\right)$, and control fish of experiment 2 also had lower chloride levels $(101.4 \pm 4.5 \mathrm{mM})$ when compared to the controls of experiment $1(131.7 \pm 4.5 \mathrm{mM})$. Plasma nitrite concentration was $0.047 \pm 0.006 \mathrm{mM}(n=6)$ for fish in control aquaria, was elevated to $0.41 \pm 0.08 \mathrm{mM}(n=5)$ after 48 hours exposure to $0.4 \mathrm{mM}$ nitrite, and declined to $0.03 \pm 0.01 \mathrm{mM}(n=7)$ after a subsequent 48 hours without nitrite contamination.

\section{Discussion}

According to the $4^{\text {th }}$ article of Resolution $n^{\circ} 20$ of the Brazilian National Environment Council (CONAMA), the maximum allowed water nitrite levels are of $1.0 \mathrm{mg} \mathrm{l}^{-1}$, around 18 times less than the nitrite added to the contaminated aquaria in the present study. However, in some locations of eutrophic rivers and lakes, or in aquaculture ponds with imbalance in biological nitrification, nitrite levels may reach $1 \mathrm{mM} \mathrm{(46} \mathrm{mg} \mathrm{l}^{-1}$ $\mathrm{NO}_{2}^{-}$) or more (Heckman et al. 1997; Jensen 2003). Another study on Nile tilapia and nitrite (Atwood et al. 2001) described a 96-hour median lethal concentration of nitrite to adult tilapias of $0.57 \mathrm{mM}\left(8 \mathrm{mgl}^{-1} \mathrm{~N}\right.$ as $\mathrm{NO}_{2}^{-}$, or $\left.26.3 \mathrm{mg} \mathrm{l}^{-1} \mathrm{NO}_{2}^{-}\right)$ a concentration slightly higher than the concentration used in the present study, allowing us to suggest that our tilapias would have shown mortality if they had been exposed for more than 2 days to nitrite, under the conditions employed.

Plasma osmolality and chloride concentrations showed a trend towards reduced values in experiment 2 as compared to experiment 1 . Indeed, both controls were different for chloride (Fig. 2b). Although there was only one month separation
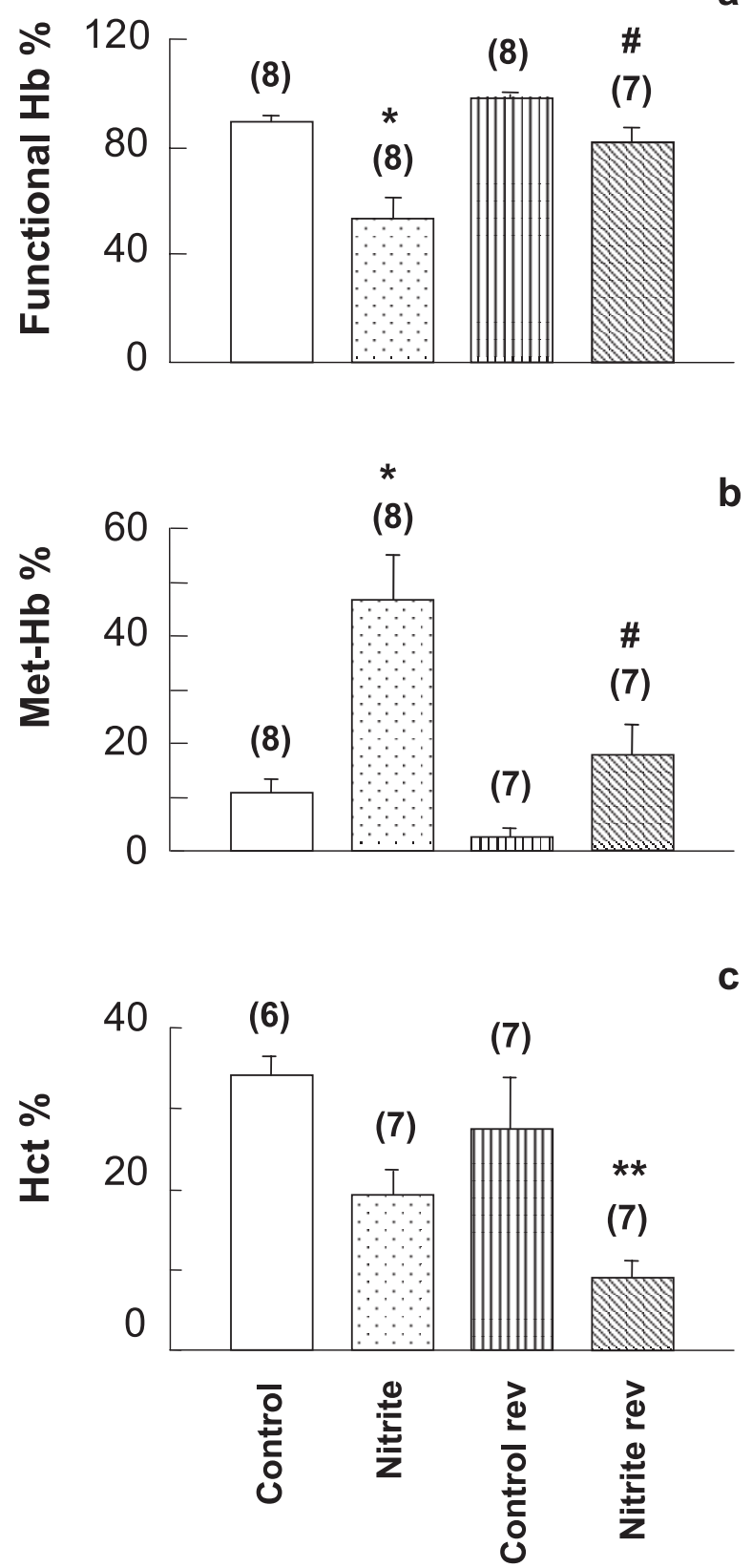

Fig. 1. Hematological parameters (mean \pm SEM) of the Nile tilapia Oreochromis niloticus submitted to 48 hours of nitrite contamination, or 48 hours of nitrite contamination followed by 48 hours without nitrite (with reversion - rev), and their respective control groups. a) functional haemoglobin $\%$; b) meta-haemoglobin $\%$; c) hematocrit. * control $x$ nitrite; ** control rev $x$ nitrite rev; \# control $x$ control rev or nitrite $x$ nitrite rev, all significant differences, with $p<0.05$. Number of animals above bars in parenthesis.

between experiments 1 and 2, differences in temperature may have triggered reproduction in the second set of animals (used for the reversion experiment). The fish for experiment 2 have been collected in early summer, and exhibited riper gonads as compared to the first set of fish. A reduced gill Na, K-ATPase activity has been observed in the brook charr during spawning activity (Le François and Blier 2000), which would be 


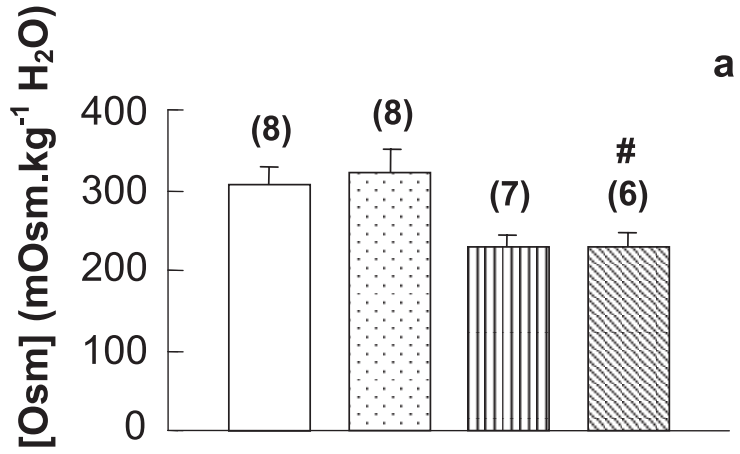

b

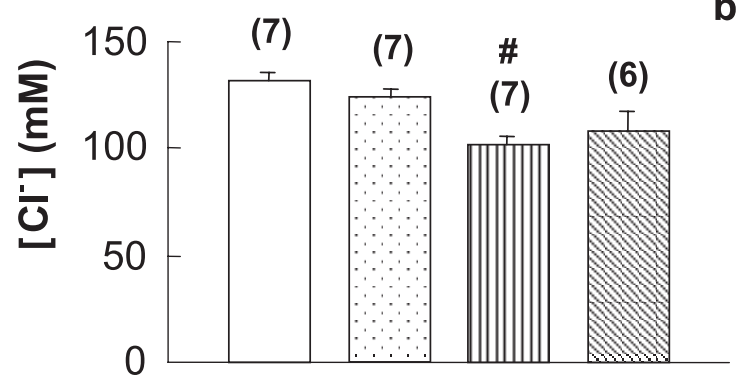

(7)

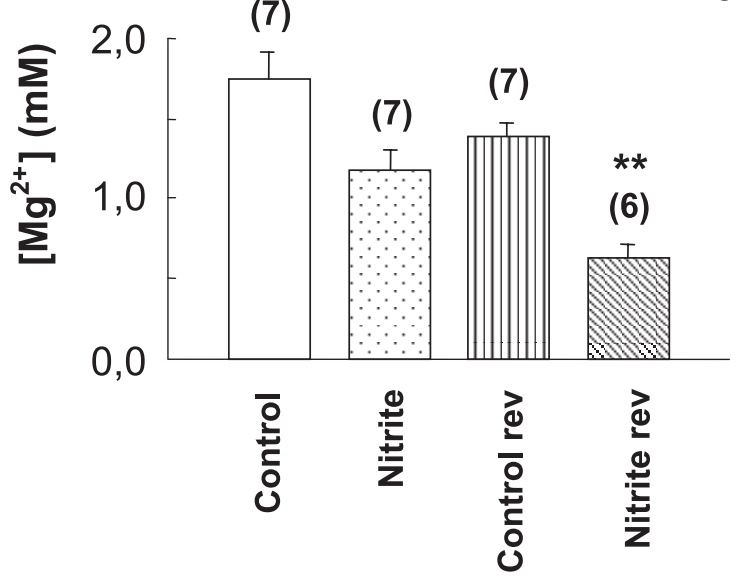

Fig. 2. Osmoregulatory parameters (mean \pm SEM) of the Nile tilapia Oreochromis niloticus submitted to 48 hours of nitrite contamination, or 48 hours of nitrite contamination followed by 48 hours without nitrite (with reversion - rev), and their respective control groups. a) plasma osmolality, mOsm kg ${ }^{-1} \mathrm{H}_{2} \mathrm{O}$; b) plasma chloride concentration, $\mathrm{mM}$ c) plasma magnesium concentration, mM. * control $x$ nitrite; $* *$ control rev $x$ nitrite rev; \# control $x$ control rev or nitrite $x$ nitrite rev, all significant differences, with $p<0.05$. Number of animals above bars in parenthesis.

consistent with the reduced osmolality and chloride levels in our tilapias from experiment 2. Although most studies report plasma chloride reduction upon nitrite exposure (Jensen et al. 1987; Williams and Eddy 1987; Jensen 2003), the lack of significant effect of nitrite on plasma chloride has been previously reported (Stormer et al. 1996; Grosell and Jensen 2000), probably resulting from moderate nitrite plasma levels.
Methaemoglobinemia is a well known effect of nitrite exposure in fish (Jensen et al. 1987; Jensen 1990; Knudsen and Jensen 1997; Adragna and Lauf 1998; Grosell and Jensen 2000; Martinez and Souza 2002; Jensen 2003). When nitrite is withdrawn, the activity of $\mathrm{Hb}$ reductase rises to normal values and methaemoglobin (MetHb) returns to control levels (Knudsen and Jensen 1997). As expected, MetHb and, in consequence, functional $\mathrm{Hb}$, returned to control values after nitrite removal. Hct would be expected to be reduced from nitrite exposure, as a result of red cell volume reduction, due to the loss of potassium. Potassium loss is due to activation of red cell $\mathrm{KCl}$ cotransport and is believed to be a consequence of conformational alterations induced by MetHb on membrane transport proteins (Jensen 1990, 2003; Martinez and Souza 2002). Hct was lowest in fish recovering from nitrite exposure, possibly refleting a delayed effect of nitrite on this hematological parameter, such as occurred with plasma $\mathrm{Mg}^{2+}$ levels. For both parameters, apparently more than 2 days of recovery would be needed for a return to control values, even though plasma nitrite had already returned to approximately zero $(\sim 0.03 \mathrm{mM})$.

Plasma $\mathrm{Mg}^{2+}$ showed a trend towards a decrease during nitrite exposure and was significantly lowered in tilapia recovering from nitrite exposure. In rainbow trout, plasma $\mathrm{Mg}^{2+}$ was increased in the most nitrite-sensitive fish, whereas more tolerant specimens showed a trend towards a decrease (Stormer et al. 1996). One may hypothesize disturbance in the renal mechanisms of plasma magnesium regulation in fresh water. It is known that nitrite removal from the body of the fish involves renal processing (Knudsen and Jensen 1997; Jensen 2003). Nitrite may interfere with magnesium absorption in the renal tubule, which could be the subject of future investigation. As the effects of nitrite are customarily perceived only through fish mortality, it would be an obvious advantage to understand the reversible effects of nitrite on the commercially important Nile tilapia.

Acknowledgements. The authors gratefully acknowledge the generous supply of a reagent for the Griess reaction and relevant nitrite literature, as well as helpful comments from Dr. Eunice Machado, the help from the personnel of the Experimental Farm of the Federal University of Paraná, the financial support from DAAD (Deutscher Akademischer Austauschdienst) providing laboratory equipment, the revision of the text by Mr. Robert Boyle, and the very helpful comments and suggestions by the anonymous referee.

\section{References}

Adragna N.C., Lauf P.K., 1998, Role of nitrite, a nitric derivate, in $\mathrm{K}-\mathrm{Cl}$ cotransport activation of low-potassium sheep red blood cells. J. Membr. Biol. 166, 157-167.

Atwood H.L., Fontenot Q.C., Tomasso J.R., Isely J.J., 2001, Toxicity of nitrite to Nile tilapia: Effect of fish size and environmental chloride. N. Am. J. Aquac. 63, 49-51.

Bendschneider K., Robinson R.J., 1952, A new spectrophotometric method for the determination of nitrite in sea water. J. Mar. Res. 11, 87-96.

Benesh R.E., Benesh R., Yung S., 1973, Equations for the espectrometric analysis of hemoglobin mixtures. Anal. Biochem. 55, 245-248. 
Bianchini A., Wasielesky Jr., W., Miranda Filho K.C., 1995, Toxicity of compounds to juveniles of flatfish Paralichthys orbignyanus. Bull. Environ. Contam. Toxicol. 56, 453-459.

Doblander C., Lackner R., 1996, Metabolism and detoxication of nitrite by trout hepatocytes. Biochim. Biophys. Acta General Subjects 1289, 270-274.

Grosell M., Jensen F.B., 2000, Uptake and effects of nitrite in the marine teleost fish Platichthys flesus. Aquat. Toxicol. 50, 97-107.

Heckman C.W., Campos J.L.E., Hardoim E.L., 1997, Nitrite concentration in well water from Poconé, Mato Grosso, and its relationship to public health in rural Brazil. Environ. Contam. Toxicol. 58, 8-15.

Jensen F.B., 1990, Nitrite and red cell function in carp: control factors for nitrite entry, membrane potassium ion permeation, oxygen affinity and methaemoglobin formation, J. Exp. Biol. 152, 149-166.

Jensen F.B., 2003, Nitrite disrupts multiple physiological functions in aquatic animals. Comp. Biochem. Physiol. A 135, 9-24.

Jensen F.B., Andersen N.A., Heisler N., 1987, Effect of nitrite exposure on blood respiratory properties, acid-base and electrolyte regulation in the carp (Cyprinus carpio). J. Comp. Physiol. B 157, 533-541.
Knudsen P.K., Jensen F.B., 1997, Recovery from nitrite-induced methaemoglobinaemia and potassium balance disturbances in carp. Fish Physiol. Biochem. 16, 1-10.

Le François N.R., Blier P., 2000, Branchial $\mathrm{Na}^{+} \mathrm{K}^{+}$ATPase activity in the brook charr (Salvelinus fontinalis): Effect of gonadal development in hypo and hyperosmotic enviroments. J. Exp. Zool. 286, 647-655.

Martinez C.B.R., Souza M.M., 2002, Acute effects of nitrite on ion regulation in two neotropical fish species. Comp. Biochem. Physiol. A 133, 151-160.

Stormer J., Jensen F.B., Rankin J.C., 1996, Uptake of nitrite, nitrate, and bromide in rainbow trout, Oncorhynchus mykiss: effects on ionic balance. Can. J. Aquat. Sci. 53, 1943-1950.

Volpato G.L., Fernandes M.O., 1994, Social control of growth in fish. Braz. J. Med. Biol. Res. 27, 797-810.

Volpato G.L., Barreto R.E., 2001, Enviromental blue light prevents stress in the fish Nile tilapia. Braz. J. Med. Biol. Res. 34, 1041-1045.

Williams M., Eddy F.B., 1987, Some effects of adrenaline on ion transport and nitrite-induced methaemoglobin formation in rainbow trout (Salmo gairdneri Richardson). J. Exp. Zool. 241, 269-273. 